\title{
Human Resource Assessment in the EAEU Countries' Companies
}

\author{
Talgat Uteubayev ${ }^{1}$, Nazgul Aidargaliyeva ${ }^{2}$, Nazgul Syrlybayeva $^{3 *}$ \\ ${ }^{1}$ Eurasian Industrial Chemical Group LLP, Karaganda, Kazakhstan \\ ${ }^{2}$ Kazakh Humanitarian Juridical Innovative University, Mangilik el Str., 11, 071400, Semey, \\ Kazakhstan \\ ${ }^{3}$ Al-Farabi Kazakh National University, Al-Farabi Ave., 71, 050040, Almaty, Kazakhstan
}

\begin{abstract}
The article conducted a survey of experts in the chemical industry to assess the human resources in the EAEU countries' companies. The hypothesis of research is due to the complex influence of the factor on human resources development, which ultimately affects the EAEU countries' innovative development. The results of the study revealed the following negative factors that impede the formation and development of human resources in Kazakhstan. In Kazakhstan, the limiting factor to the technological breakthrough in the long term is the quality of human resources. There is a tendency to increase the outflow of promising youth and qualified personnel from Kazakhstan. The development of human resources in Kazakhstan is significantly affected by the lack of interest in the business environment in the additional costs of training and professional development of workers, as well as low wages of employees.
\end{abstract}

\section{Introduction}

Human resources are the most important factor in economic growth, production and competitiveness of the enterprise, territories and the State. The industrial society development, which is increasingly moving to a new phase - information, requires appropriate human resources. Innovative technologies, new forms of production put forward new requirements for human resources, emphasizing the need for highly qualified specialists and a creative approach to work, which, in turn, set the stage for changes in human resources management techniques and tools.

Human resource management in modern conditions is a determining tool in the enterprise management mechanism. The abilities of the enterprise employees, their level of education, as well as qualifications and experience to a large extent determine the ability of the enterprise to use existing resources and the final results of work. The successful application of the human resource management theory in practice is one of the most important areas of strategic management in modern international companies. In their work, they use the postulates and provisions developed by theoreticians and the practice of HR management for years, as well as independently, continuously improve their skills and accumulate experience in managing human resources.

\footnotetext{
*Corresponding author: adilet-75@mail.ru
} 
Industrial, economic, natural, cultural and human resources predetermine the potential of the State and the integration associations of the world. The wise use of these resources is an important subject of regulation at the macro level. Human resources, among all other resources, act as an indicator of the level of development of the State.

The EAEU with its population and composition is a unique integration entity. In this regard, the assessment of human resources in Kazakhstan and other EAEU countries should be carried out on the basis of a comprehensive analysis that affects all aspects of the population life, using both quantitative and qualitative indices. Only with such an analysis of human resources can one really predict the structure, composition and realization of their potential in the future. There is an urgent need for the identification and subsequent solution of the problems of human resource management in the context of a new integration association - the Eurasian Economic Union.

The functioning of the human resources management mechanism in each organization is an individual process. Nevertheless, the analysis of labor relations at homogeneous enterprises, taking into account the specifics of the industry, allows us to identify general trends and patterns, evaluate and identify problems in the human resources management system. The relevance of the human resources management system analysis at the enterprises of the chemical industry in the EAEU countries is determined by the presence of wide interstate relations and private initiatives in comparison with other industries, and the similarity of problems in the development of the industry.

In this regard, the experience of enterprises in the chemical industry can become the basis for identifying common labor trends and problems requiring improvement of the human resources management system, or the need for government intervention in the conditions of use of human resources.

\section{Brief Literature Review}

Currently, the chemical industry enterprises in the EAEU countries are mostly large industrial complexes [1]. Their experience in human resource management shows that a very objective situation has developed in the EAEU countries: on the one hand, enterprise managers understand the importance of human resources and the need for their development $[2,3,4,5]$, on the other hand, they remain attached to the predominance of the traditional administrative management system, with the realization that this system is modern does not correspond to market conditions [6, 7, 8, 9,10]. Currently, Kazakhstan is undergoing economic reforms: the main directions for modernizing the economy based on the introduction of advanced technologies have been formulated before society. In this regard, the need to increase the competitiveness of goods and services produced in Kazakhstan is obvious, which together require the search for new approaches to human resource management $[10,11,12,13,14]$.

At that time, foreign enterprises are in constant search of new human resources management tools, enterprises of Kazakhstan and other EAEU countries in this direction are significantly behind $[15,16,17,18,19]$.

Therefore, in the chemical industry companies, in the conditions of further modernization of the Kazakhstani economy, special attention should be paid to issues of increasing the level of work with human resources, to carry out work in this direction based on a scientific approach, using the accumulated domestic and foreign experience.

\section{Materials and methods}


As part of the human resource assessment in the EAEU countries' companies, the article conducted a survey of experts in the chemical industry of the EAEU countries.

The purpose of sociological research is the human resource assessment in the EAEU countries' companies.

The hypothesis of sociological research is due to the complex influence of the factor on the human resources development, which ultimately affect the EAEU countries' innovative development.

Objectives of a sociological study:

- assess key areas of the human resources formation and development in the EAEU countries;

- assess the factors that impede the human resources formation and development in the EAEU countries.

The study involved thirty-two experts (heads of enterprises, structural divisions, and heads of personnel services) of nine companies in the EAEU countries' chemical industry. The questionnaire was conducted during the annual XI Astana Economic Forum held in Nur-Sultan from 17 to 19 May 2018. The forum brought together more than 5,000 delegates from 80 countries, including representatives of the EAEU countries' chemical industry. The limited scope of the questionnaire is due to the fact that the study was conducted alone.

\section{Results and discussion}

All interviewed experts are representatives of the EAEU countries' chemical industry, whose main activity is the production of rubber products: molded and non-molded products, conveyor belts, sleeves, technical plates, etc. (table 1).

Table 1. EAEU countries' chemical industry enterprises that participated in the survey, 2018.

\begin{tabular}{|l|l|l|c|c|}
\hline \multicolumn{1}{|c|}{ Company name } & Country & Type of ownership & $\begin{array}{c}\text { Number of } \\
\text { employees }\end{array}$ & $\begin{array}{c}\text { Number of } \\
\text { experts } \\
\text { surveyed }\end{array}$ \\
\hline $\begin{array}{l}\text { Eurasian Industrial } \\
\text { Chemical Group LLP }\end{array}$ & Kazakhstan & private partnership & 1221 & 5 \\
\hline Ak Bult LLP & Kazakhstan & private partnership & 568 & 4 \\
\hline VASTE LLP & Kazakhstan & private partnership & 235 & 5 \\
\hline Metafrax OJSC & Russia & private company & 1456 & 4 \\
\hline $\begin{array}{l}\text { BARNAUL SHRZ } \\
\text { OJSC }\end{array}$ & Russia & private company & 857 & 3 \\
\hline Belkhim OJSC & Belarus & private company & 3564 & 4 \\
\hline $\begin{array}{l}\text { Rezino Technika } \\
\text { OJSC }\end{array}$ & Belarus & private company & 265 & 3 \\
\hline Interhim LLC & Kyrgyzstan & private company & 356 & 2 \\
\hline MOBILE-TIVI LLC & Armenia & private company & 236 & 2 \\
\hline
\end{tabular}

Note - Compiled by the authors

As can be seen from the data in table 1, all nine companies have a private form of ownership with a different number of employees.

Interviewed experts evaluated the complex socio-economic aspects (based on a study of literature, the media we developed 24 factors) that impede the development of human resources in each of the EAEU countries, directly affecting the innovative development of national economies (these factors were evaluated on a five-point scale, 1 - 
the minimum value or to a lesser extent, 5 - the maximum value or to a greater extent) (table 2).

Table 2. Negative factors affecting the human resources development in the EAEU countries' chemical industry companies.

\begin{tabular}{|c|c|c|c|c|c|}
\hline Factors & $\begin{array}{l}\text { Arme } \\
\text { nia }\end{array}$ & Belarus & $\begin{array}{l}\text { Kazakh } \\
\text { stan }\end{array}$ & $\begin{array}{l}\text { Kyrgyzsta } \\
\mathrm{n}\end{array}$ & Russia \\
\hline Outflow of qualified personnel & 4.02 & 3.28 & 3.92 & 4.2 & 3.86 \\
\hline $\begin{array}{l}\text { The attractiveness of near and far- } \\
\text { abroad countries for study and } \\
\text { residence }\end{array}$ & 3.95 & 3.12 & 3.84 & 4.12 & 2.41 \\
\hline $\begin{array}{l}\text { Disinterest of the business environment } \\
\text { in the additional costs for training and } \\
\text { professional development } \\
\text { employees, etc. }\end{array}$ & 3.87 & 3.58 & 3.78 & 3.97 & 3.92 \\
\hline Low wages for employees & 3.86 & 3.05 & 3.72 & 3.85 & 3.14 \\
\hline $\begin{array}{l}\text { Regional specialization of the country } \\
\text { and economic risks in this regard }\end{array}$ & 2.98 & 2.19 & 3.69 & 3.79 & 2.58 \\
\hline $\begin{array}{l}\text { Insufficient level of investment in the } \\
\text { manufacturing sector of the country's } \\
\text { economy }\end{array}$ & 2.66 & 2.26 & 3.26 & 3.94 & 3.82 \\
\hline $\begin{array}{l}\text { Low level of business education in the } \\
\text { country }\end{array}$ & 3.22 & 3.04 & 3.21 & 3.77 & 3.18 \\
\hline $\begin{array}{l}\text { Lack of cultural facilities, especially in } \\
\text { remote regions }\end{array}$ & 2.41 & 2.88 & 3.18 & 3.45 & 3.05 \\
\hline $\begin{array}{l}\text { Low motivation of the population to } \\
\text { work }\end{array}$ & 3.85 & 4.16 & 3.15 & 3.38 & 3.08 \\
\hline $\begin{array}{l}\text { Lack of qualified personnel in the } \\
\text { healthcare system, education }\end{array}$ & 3.21 & 2.87 & 3.08 & 3.86 & 3.28 \\
\hline Weak population culture & 2.85 & 2.45 & 3.0 & 3.36 & 2.99 \\
\hline $\begin{array}{l}\text { Lack of competence and knowledge } \\
\text { centers }\end{array}$ & 3.17 & 3.62 & 2.87 & 3.08 & 2.48 \\
\hline $\begin{array}{l}\text { Lack of a human resources } \\
\text { management system at the state level }\end{array}$ & 4.02 & 2.17 & 2.78 & 3.28 & 2.95 \\
\hline $\begin{array}{l}\text { Low quality of implemented state } \\
\text { programs }\end{array}$ & 2.85 & 2.14 & 2.75 & 3.86 & 3.62 \\
\hline Underdeveloped infrastructure & 3.57 & 2.46 & 2.69 & 3.32 & 2.54 \\
\hline $\begin{array}{l}\text { Insufficient level of control over the } \\
\text { implementation of state human } \\
\text { development programs }\end{array}$ & 2.08 & 2.02 & 2.58 & 3.33 & 3.45 \\
\hline $\begin{array}{l}\text { Lack of advocacy for finding a job, } \\
\text { continuing education, retraining }\end{array}$ & 3.14 & 2.04 & 2.54 & 3.24 & 2.44 \\
\hline $\begin{array}{l}\text { Arbitrariness of state and law } \\
\text { enforcement bodies }\end{array}$ & 2.78 & 2.04 & 2.45 & 3.74 & 2.34 \\
\hline Inability to get a job due to nepotism & 3.54 & 2.06 & 2.43 & 3.79 & 3.14 \\
\hline $\begin{array}{lll}\begin{array}{l}\text { Ecology, } \\
\text { problems }\end{array} & \text { environmental pollution } \\
\end{array}$ & 2.78 & 2.05 & 2.41 & 2.85 & 2.55 \\
\hline $\begin{array}{l}\text { Lack of educational facilities, } \\
\text { healthcare }\end{array}$ & 2.47 & 2.08 & 2.4 & 3.17 & 2.21 \\
\hline Corruption at all levels of government & 2.14 & 2.0 & 2.37 & 3.76 & 3.04 \\
\hline The growth of crime and delinquency & 2.18 & 2.0 & 2.30 & 3.14 & 2.47 \\
\hline Addiction, alcoholism of the population & 2.04 & 2.14 & 2.07 & 2.87 & 2.24 \\
\hline
\end{tabular}

Note - Compiled by the authors 
From the data in Table 2 it follows that the most significant factors affecting the human resources development for Kazakhstan are such aspects as the outflow of qualified personnel, the attractiveness of the countries of near and far-abroad for study and residence, the disinterest of the business environment in the additional costs of staff development, as well as low wages for employees.

\section{Conclusion}

The results of the study allow us to draw the following conclusions:

1. In Kazakhstan, the quality of human resources is a constraining factor for the technological breakthrough in the long run. In this situation, in our opinion, in Kazakhstan it is necessary to improve the healthcare and education system, restructure the investment portfolio in healthcare and education - areas where investments are aimed at improving the quality of human resources in the long term based on public-private partnership mechanisms.

2. The results of the study confirm the upward trend in the outflow of promising young people and qualified personnel from Kazakhstan in the EAEU. At the same time, Kazakhstani youth mainly chooses Russia as a new place. In our opinion, this is facilitated by the relatively well-organized migration policy of the Russian Federation. Young people studying in Russian universities have the opportunity both to obtain Russian citizenship and to find employment at the place of study.

3. The human resources development in Kazakhstan is significantly affected by the lack of interest in the business environment in the additional costs of training and professional development of workers, as well as low wages of workers. In our opinion, the mechanism of public-private partnership in the field of training potential employees can be considered as an effective way to attract private investment in updating the infrastructure of the education system to meet their modern world standards.

\section{References}

1. N.A. Kurmanov, A.N. Toksanova, A.A. Mukhamedzhanova, N.Sh. Syrlybaeva, M.M. Petrova, The Journal of Economic Research \& Business Administration, 4:126, 35-51 (2018)

2. T.A. Kussainov, M. Maitah, N.A. Kurmanov, P. Hájek, B.S. Tolysbaev, A.K. Baidakov, Review of European Studies, 7:11, 125-131 (2015) doi:10.5539/res.v7n11p125

3. A. Yeleussov, N. Kurmanov, B. Tolysbayev, Actual Problems of Economics, 2:164, 142-150 (2015)

4. N. Kurmanov, B. Tolysbayev, D. Aibossynova, N. Parmanov, Economic Annals XXI, 158:3-4, 57-61 (2016) DOI: http://dx.doi.org/10.21003/ea.V158-13

5. A.K. Maralov, K.A. Kirdasinova, N. Kurmanov, G. Kabdullina, M. Uandykova, International Journal of Supply Chain Management, 8:2, 268-276, (2019)

6. N. Kurmanov, B. Beisengaliyev, A. Dogalov, D. Turekulova, N. Kurmankulova, International Journal of Economics and Financial Issues, 6:4, 1440-1445 (2016)

7. S. S. Baktymbet, A. S. Baktymbet, N. A. Kurmanov, A. Zh. Satbayeva, Bulletin of the National Academy of Sciences of the Republic of Kazakhstan, 2, 160-169 (2017)

8. N. Kurmanov, U. Aliev, S. Suleimenov, Polish Journal of Management Studies, 19:1, 204-214 (2019) DOI: 10.17512/pjms.2019.19.1.15 
9. N. Kurmanov, M. Petrova, S. Suleimenova, E3S Web Conf., 105, 04045 (2019) https://doi.org/10.1051/e3sconf/201910504045

10. N. Kurmanov, A. Yeleussov, U. Aliyev, B. Tolysbayev, Mediterranean Journal of Social Sciences, 6:5 (S1), 54-61 (2015) Doi:10.5901/mjss.2015.v6n5s1p54

11. T. Uteubayev, International Journal of Economics and Financial Issues, 6:4, 14191423. (2016)

12. N. Kurmanov, U. Aliyev, A. Rakhimbekova, A. Makhatova, Bulletin of the National Academy of Sciences of the Republic of Kazakhstan, 5, 46-54 (2016)

13. S. S. Baktymbet, N. A. Kurmanov, A. S. Baktymbet, Bulletin of the National Academy of Sciences of the Republic of Kazakhstan, 4, 141-149 (2016)

14. N. Kurmanov, D. Turekulova, G. Doskeyeva, G. Alina, International Journal of Economics and Financial Issues, 6:3, 907-910 (2016)

15. N. A. Kurmanov, B. K. Zhumanova, O. V. Kirichok, World Applied Sciences Journal, 21:10, 1495-1501 (2013) DOI: 10.5829/idosi.wasj.2013.21.10.2952

16. N. Kurmanov, VIth Ryskulov Readings: Socio-Economic Modernization of Kazakhstan under conditions of global financial instability, 1186-1198 (2012)

17. N. Kurmanov, D. Aibosynova, CBU International Conference Proceedings, 3, 129-140 (2015)

18. D. Turekulova, B. Beisengaliyev, B. Zhumanova, F. Dosmambetova, N. Syrlybayeva, Life Sci J,11:7s, 48-51 (2014)

19. N. Kurmanov, A. Dogalov, S. Toktasynov, A. Baktymbet, S. Baktymbet, A. Rakhimbekova, A. Satbayeva, International Review of Management and Marketing, 7:1, 458-464 (2017) 